\title{
Large-scale analysis of protein expression changes in human keratinocytes immortalized by human papilloma virus type 16 E6 and E7 oncogenes
}

\author{
Mark A Merkley ${ }^{\dagger 1}$, Ellen Hildebrandt ${ }^{1,5}$, Robert H Podolsky ${ }^{2}$, Hilal Arnouk ${ }^{1,6}$, \\ Daron G Ferris ${ }^{3,4}$, William S Dynan ${ }^{1}$ and Hubert Stöppler*1,3
}

\begin{abstract}
Address: ${ }^{1}$ Institute of Molecular Medicine and Genetics, Medical College of Georgia, Augusta, GA, USA, ${ }^{2}$ Center for Biotechnology and Genomic Medicine, Medical College of Georgia, Augusta, GA, USA, ${ }^{3}$ Department of Obstetrics and Gynecology, Medical College of Georgia, Augusta, GA, USA, ${ }^{4}$ Department of Family Medicine, Medical College of Georgia, Augusta, GA, USA, ${ }^{5}$ Department of Microbiology and Immunology, Louisiana State University Health Sciences Center, Shreveport, Louisiana 71130, USA and ' ${ }^{D}$ ivision of Hematology/Oncology, Department of Medicine, University of Alabama at Birmingham, Birmingham, Alabama 35294, USA
\end{abstract}

Email: Mark A Merkley - mmerkley@mail.mcg.edu; Ellen Hildebrandt - ehilde@lsuhsc.edu; Robert H Podolsky - rpodolsky@mail.mcg.edu; Hilal Arnouk - harnouk2@yahoo.com; Daron G Ferris - dferris@mail.mcg.edu; William S Dynan - wdynan@mail.mcg.edu;

Hubert Stöppler* - stopplerh@cc.uscsf.edu

* Corresponding author †Equal contributors

Published: 23 August 2009

Proteome Science 2009, 7:29 doi:10.1186/1477-5956-7-29

This article is available from: http://www.proteomesci.com/content/7/1/29

(c) 2009 Merkley et al; licensee BioMed Central Ltd.

This is an Open Access article distributed under the terms of the Creative Commons Attribution License (http://creativecommons.org/licenses/by/2.0), which permits unrestricted use, distribution, and reproduction in any medium, provided the original work is properly cited.
Received: 5 June 2009

Accepted: 23 August 2009

\begin{abstract}
Background: Infection with high-risk type human papilloma viruses (HPVs) is associated with cervical carcinomas and with a subset of head and neck squamous cell carcinomas. Viral E6 and E7 oncogenes cooperate to achieve cell immortalization by a mechanism that is not yet fully understood. Here, human keratinocytes were immortalized by long-term expression of HPV type 16 E6 or E7 oncoproteins, or both. Proteomic profiling was used to compare expression levels for 741 discrete protein features.
\end{abstract}

Results: Six replicate measurements were performed for each group using two-dimensional difference gel electrophoresis (2D-DIGE). The median within-group coefficient of variation was 19$21 \%$. Significance of between-group differences was tested based on Significance Analysis of Microarray and fold change. Expression of 170 (23\%) of the protein features changed significantly in immortalized cells compared to primary keratinocytes. Most of these changes were qualitatively similar in cells immortalized by E6, E7, or E6/7 expression, indicating convergence on a common phenotype, but fifteen proteins $(\sim 2 \%)$ were outliers in this regulatory pattern. Ten demonstrated opposite regulation in E6- and E7-expressing cells, including the cell cycle regulator pI6INK4a; the carbohydrate binding protein Galectin-7; two differentially migrating forms of the intermediate filament protein Cytokeratin-7; HSPAIA (Hsp70-I); and five unidentified proteins. Five others had a pattern of expression that suggested cooperativity between the co-expressed oncoproteins. Two of these were identified as forms of the small heat shock protein HSPBI (Hsp27).

Conclusion: This large-scale analysis provides a framework for understanding the cooperation between E6 and E7 oncoproteins in HPV-driven carcinogenesis. 


\section{Background}

The oral cavity, oropharynx, larynx, esophagus, and anogenital orifices are lined with stratified squamous nonkeratinized epithelium, which forms the barrier between the underlying tissue and the environment. The proliferative nature of this epithelium, together with its potential exposure to environmental insults such as oncogenic viruses makes it susceptible to carcinogenesis. Indeed, carcinomas of stratified squamous nonkeratinized epithelium are among the most common and deadly cancers worldwide. Cervical squamous cell cancer is the second leading cause of death among women and is responsible for loss of 3.3 million life-years annually. Although head and neck squamous cell cancer is a more heterogeneous disease, it is the sixth most commonly diagnosed malignancy worldwide and also imposes a significant global health burden.

Infection with high-risk subtype mucosatropic human papillomavirus (HPV) is associated with $99.7 \%$ of cervical cancers $[1,2]$ and for a subset of head and neck squamous cell carcinomas and anal squamous cell carcinomas [3-8]. Expression of the HPV E6 and E7 oncoproteins promotes neoplastic transformation by altering expression or interfering with the function of proteins involved in cell proliferation and apoptosis (reviewed in [9,10]). E6 expression influences the stability or function of proteins including TP53, hScrib, hDlg, MUPP1, p300, NF-kb, and IRF-3 [1113]. Many of the effects of E6 are attributable to its interaction with E6-associated protein (E6AP), an E3 ubiquitin ligase, although some effects are E6AP-independent [14$16]$. E7 binds to the retinoblastoma protein $(\mathrm{Rb})$ and disrupts the $\mathrm{Rb} / \mathrm{E} 2 \mathrm{~F} / \mathrm{HDAC}$ complex. This abolishes the transcriptional trans-repressor functions of the complex and leads, via E2F release, to the induction of the transcriptional trans-activation function of E2F (reviewed in [17]). Additionally, E7 binds directly to cyclin A- and E-dependent kinase complexes, and E7-dependent inhibition of the cyclin-dependent kinase inhibitors p21 and p27 has been demonstrated [17-19]. Both E6 and E7 have been shown to play a role in the suppression of the immune response to infection $[20,21]$.

Expression of either high-risk HPV E6 or E7 in human keratinocytes extends the period of growth prior to senescence well beyond normal. Combined expression of E6 and E7, however, is more efficacious than their individual expression in promoting cellular immortalization $[10,15,22-25]$. The two viral oncogenes target different cellular regulatory pathways, and their combined expression induces cell proliferation and simultaneously suppresses the apoptotic response associated with oncogeneinduced unscheduled cell proliferation.

We report here the results of a large-scale analysis to quantify the extent to which proteomic profiles differ from each other in cells that have been immortalized by the expression of E6 or E7 individually and in combination. We used an in vitro model consisting of primary human foreskin keratinocytes (HFKs) immortalized by transduction with HPV oncogenes [26]. The methodology used for our study was 2D-differential gel electrophoresis (2DDIGE), which involves co-electrophoresis of experimental samples with a differentially labeled internal standard [27]. This technique has been widely applied previously for clinical proteomics, providing a basis for comparison between results in the in vitro model and clinical studies. Proteomic methods have been used previously to characterize E6- and E7-associated proteins. Two studies identified proteins modulated by transfection of E7 $[28,29]$ and one study identified proteins modulated by transfection of E6 [30]. However, these were based on expression of viral oncogenes E6 and E7 individually into established cancer cell lines. The earlier studies did not include the comparison to primary cells and to cells expressing both oncogenes simultaneously that provide the underlying analytical framework in the present study.

We determined that 170 out of 741 spots (23\%) were significantly different in abundance in immortalized cells versus HFKs. The overwhelming majority of these showed qualitatively similar changes regardless of which oncogene drove the immortalization. We assume that the vast majority of these alterations are not directly associated with viral oncogene expression, but that they are rather a consequence of cell immortalization. The most interesting features of the data set may be the small number of outliers that did not follow this general trend, including ten protein features oppositely regulated in E6- vs. E7transduced cell populations, compared to HFKs, and five that showed significantly higher expression in the E6/7transduced population than was expected, based on results in cells transduced with E6 or E7 alone.

\section{Results \\ 2D-DIGE analysis}

The method of generating HFK-derived cell populations expressing HPV 16 E6, E7, or both E6 and E7 (E6/7) oncoproteins has previously been described [26]. Continuous cultivation leads to the establishment of immortalized keratinocyte cultures expressing the HPV oncogenes and derived from a genetically identical host background [26]. Cell lysates of the immortalized HPV oncogene-expressing cultures and a primary, non-HPV oncogene-expressing HFK culture were harvested for proteome characterization.

Figure 1 illustrates the experimental workflow and quality control metrics for the study. There were 24 analytical gels in the experiment, representing six replicates of each of the four experimental groups: non-immortalized HFKs, E6-transduced keratinocytes, E7-transduced keratinoc- 


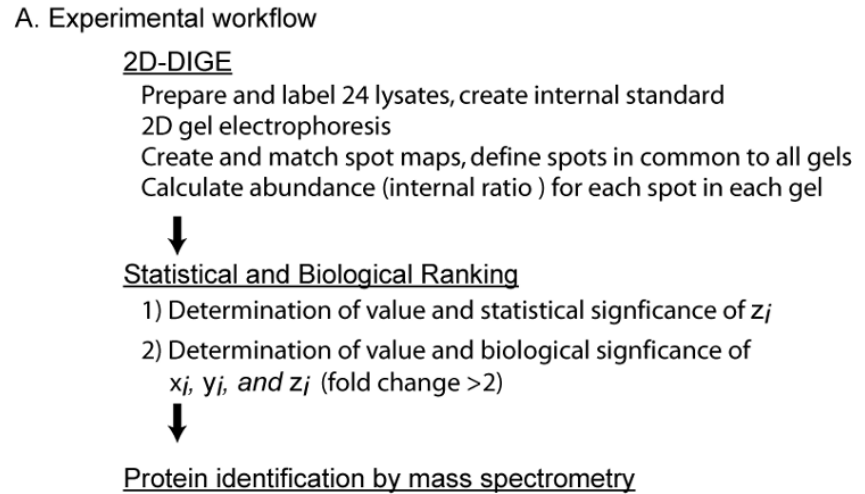

B. Coefficients of variation

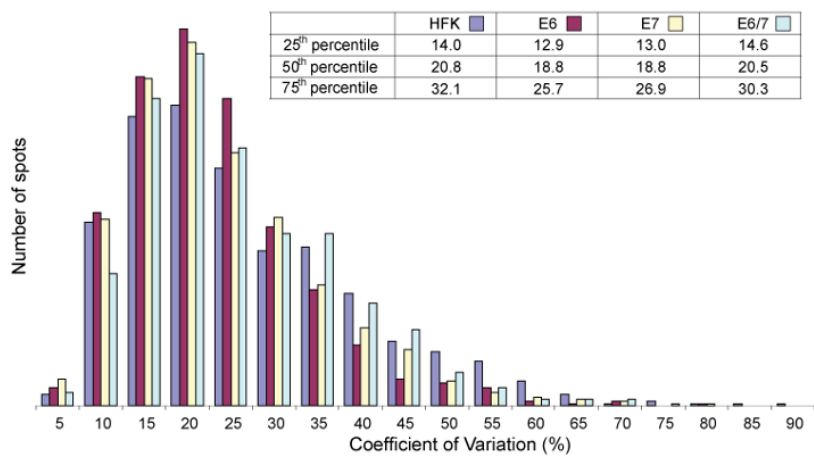

Figure I

Workflow and quality control metrics. A. Experimental workflow. B. Histogram showing coefficients of variation.

Colors distinguish HFK, E6, E7, and E6/7 groups as indicated in the key.

ytes, and E6/7-transduced keratinocytes. Each gel contained $1 \mu \mathrm{g}$ of cell lysate from an experimental sample labeled with Cy5 and $1 \mu \mathrm{g}$ of internal standard labeled with Cy3 dye. The internal standard consisted of an equal mixture of cell lysates from all 4 experimental groups (for further details on experimental design see Methods and Figure 1A). Saturation cysteine labeling (as opposed to minimal labeling at lysine residues) was chosen so that spot mobility would be as similar as possible to a prior clinical study [31]. Following two-dimensional electrophoresis, DeCyder software was used to create a spot map for each gel. The presence of the invariant internal standard facilitated matching spots across the gel set. An average of 1812 spots per gel matched to the master spot map, and 741 spots were common to all gels. For each of these 741 spots, we calculated relative abundance as described in the Methods section. For each spot, we then determined the mean increments in expression in E6-transduced cultures, E7-transduced cultures, and E6/7 transduced cultures, relative to HFKs. We expressed these parameters on a $\log _{2}$-transformed scale and designated them as $\mathrm{x}_{i}, \mathrm{y}_{i}$, and $\mathrm{w}_{i}$, respectively, where $i$ is the spot number (i.e., a unit increment in $\mathrm{x}_{i}, \mathrm{y}_{i}$, and $\mathrm{w}_{i}$ represents a two-fold change in relative abundance). We defined a fourth parameter, $z_{i}$, as the difference between the actual increment in expression in E6/7-transduced cells and the predicted increment based on the sum of $\mathrm{x}_{i}$ and $\mathrm{y}_{i}$. Based on this definition, we shall refer to $z_{i}$ as an "E6/7 interaction" parameter. The derivation of these parameters from the experimental data is explained in more detail in Additional file 1.

To evaluate reproducibility of the abundance measurements, we determined within-group coefficients of variation (CVs) (Figure 1B). The median CV for each group ranged from $18.8 \%$ to $20.8 \%$, indicating that withingroup variation was small, relative to the anticipated between-group differences.

\section{Identification of proteins of interest}

To identify the most interesting features in the data set, we characterized proteins according to statistical and biological significance as detailed in Additional file 1. Briefly, Significance Analysis of Microarray (SAM) was first used to classify the spots according to whether the E6/7 interaction parameter $z_{i}$ was significant $\left(z_{i} \approx 0\right.$ versus $\left.z_{i} \neq 0\right)$. For spots where $z_{i} \approx 0$, we were able to use statistically powerful group comparisons and SAM analysis to evaluate $\mathrm{x}_{i}$ and $\mathrm{y}_{i}$. We used a false discovery rate (FDR) $<5 \%$ as a threshold for statistical significance, and $\left|\mathrm{x}_{i}\right|$ or $\left|\mathrm{y}_{i}\right|>1$ (corresponding to a minimum 2-fold change associated with E6 or E7 expression) as a threshold of biological significance. For spots where statistical significance of $z_{i}$ was established by the initial SAM analysis (E6/7-associated increment in expression significantly more or less than predicted by the sum of the E6 and E7-associated increments, $x_{i}$ and $\left.y_{i}\right)$, a value of $\left|x_{i}\right|$ or $\left|y_{i}\right|>1$ was used as a further test of biological significance. Based on these criteria, $170 / 741$ spots $(23 \%)$ were evaluated as significant. These could be classified in eight combinatorial groups based on the algebraic sign of $\mathrm{x}_{i}, \mathrm{y}_{i}$ and $z_{i}$ (Table 1).

We selected 65 significant spots for mass spectrometry analysis. We ran a separate preparative gel, matched it to the master analytical gel, and picked and identified spots as described in Materials and Methods. We identified 42 spots $(65 \%)$ with a Mascot score $>113$ (confidence level of identification 100\%), $13(20 \%)$ with a Mascot score of 65-112 (confidence level of identification > 95\%), and failed to identify 10 spots (15\%). Figure 2 shows a subset of the identified proteins projected on a representative $2 \mathrm{D}$ gel image. There were several instances where nearby spots were identified as the same protein, probably reflecting charge modification. All identified proteins migrated within a range consistent with expected mass and pI values. Identified proteins are listed in Table 2, with further details of the identification listed in Additional file 1, Table S1. 


\section{Correlation of 2D-DIGE analysis and immunoblotting results}

We selected four identified proteins for confirmatory immunoblot analysis (Figure 3). Proteins were chosen based on the availability of high quality antibodies and on a preliminary analysis of the 2D-DIGE data. We carried out individual and grouped comparisons as described in the legend to Figure 3, using values obtained by 2D-DIGE or immunoblotting. The scatter plot (panel C) indicates the relationship obtained by using each data set. Values were plotted on a log-transformed scale such that a unit increment on each axis corresponds to a 2-fold change in relative abundance. For each protein, a strong correlation $\left(\mathrm{r}^{2}>0.8\right)$ was seen. We noted that, although values were highly correlated, the slopes of the best-fit lines were uniformly $<1$ (i.e., the magnitude of differences measured by immunoblotting are less than those measured by 2DDIGE). We suspect that the quantitative discrepancy with the 2D-DIGE and immunoblotting results arises because of the limited dynamic range of the film-based method for detecting the ECL signal (Methods).

\section{Analysis of expression patterns}

To help visualize large-scale patterns in the data, we generated a heatmap by unsupervised clustering using the 170 protein features that met criteria for significance (Figure 4A). The primary HFKs form a clear outgroup, whereas the immortalized populations can be seen to have converged on a broadly similar phenotype. The six replicates in each experimental group (E6, E7, and E6/7) cluster together, and within each experimental group the technical replicates (collected at the same population doubling level) cluster more closely than the biological replicates (clustered at a subsequent population doubling).

To more clearly distinguish outliers in the overall proteomic pattern, we plotted $\mathrm{x}_{i}, \mathrm{y}_{i}$, and $\mathrm{z}_{i}$ parameters associated with all 741 spots in the study as a three-dimensional graph (Figure 4B). Most spots (>97\%) fall into a "main sequence" - a cluster with near-continuous distribution of $\mathrm{x}_{i}, \mathrm{y}_{i}$, and $\mathrm{z}_{i}$ values. At the center of the cluster (grey squares) are spots with expression changes that were not significant by any criterion. Surrounding this core are spots where $z_{i} \neq 0$ but where effects of E6 and E7 transduction were too weak to meet the threshold of biological significance (grey circles). Neither of these groups was characterized further.

In front and below the central grey spots are 57 spots (yellow) that were evaluated as significant and share the common property that $x_{i}>0, y_{i}>0$. That is, expression was upregulated in both E6-transduced and E7-transduced cells (although not necessarily to the same extent). For all the spots in this group, $z_{i}$ was also less than zero $\left(z_{i}<0\right.$ and significant for circles, $z_{i}<0$ but non-significant for squares). This indicates that although the spots were upregulated in the E6/7-transduced cells, the effect was not as great as predicted based on the observed $\mathrm{x}_{i}, \mathrm{y}_{i}$ values, assuming independent E6 and E7 effects. Identified proteins in this group are listed in Table 2, and include an

Table I: Significant spots categorized by expression pattern

\begin{tabular}{ccccccc}
\hline Trend & $\mathbf{x}_{i}$ & $\mathbf{y}_{i}$ & $\mathbf{z}_{i}$ & $\mathbf{n}$ (spots) & $\mathbf{n}$ (significant) & Examples \\
\hline Up-regulated in oncogene-expressing cells & $>0$ & $>0$ & $<0$ & 325 & 57 & $\begin{array}{c}\text { Oncoprotein DJ-I, ezrin, multiple HSPs, metabolic, } \\
\text { and regulatory proteins }\end{array}$ \\
\cline { 2 - 7 } & $>0$ & $>0$ & $>0$ & 31 & 5 & HSPBI (2 forms), peroxiredoxin-3 \\
\hline Mixed regulation in oncogene-expressing cells & $>0$ & $<0$ & $<0$ & 21 & 4 & HSPAI \\
\cline { 2 - 6 } & $>0$ & $<0$ & $>0$ & 38 & 0 & (none) \\
\cline { 2 - 7 } & $<0$ & $>0$ & $>0$ & 49 & 3 & Pl6ink4a, keratin 7 (2 forms) \\
\cline { 2 - 6 } & $<0$ & $>0$ & $<0$ & 69 & 3 & Galectin-7 \\
\hline (none)
\end{tabular}

All 74I protein spots were classified according to the algebraic sign of $x_{i}, y_{i}$, and $z_{i}$. For each of eight possible permutations, the table provides the total number of spots and the number of spots evaluated as potentially significant using statistical and biological criteria specified in Additional file I. The table also provides examples of identified proteins in each category. 
Table 2: Spots identified by mass spectrometry

\begin{tabular}{|c|c|c|c|c|c|c|c|c|}
\hline Group & spot number & Protein name & Gene name & $\begin{array}{l}\text { UniProt Accession } \\
\text { Number }\end{array}$ & DC-I & DC-2 & GC-C & DC-3 \\
\hline & & & & & $2^{x i}$ & $2 y i$ & $2^{z i}$ & $2^{w i}$ \\
\hline \multirow{15}{*}{$\begin{array}{l}\text { Down-regulated } 2 x i<1, \\
\qquad 2^{y i}<1\end{array}$} & 572 & Keratin, type II cytoskeletal 6C & KRT6C & P48668 & 0.32 & 0.19 & 4.47 & 0.27 \\
\hline & 560 & Keratin, type II cytoskeletal 6C & KRT6C & P48668 & 0.35 & 0.21 & 4.13 & 0.3 \\
\hline & 545 & Pyruvate kinase isozyme M2 & PKM2 & $\mathrm{PI} 4618$ & 0.37 & 0.14 & 7.14 & 0.36 \\
\hline & 1110 & Annexin $A 2^{b}$ & ANXA2 & Q8TBV2 & 0.38 & 0.66 & 1.36 & 0.34 \\
\hline & 775 & $\begin{array}{l}\text { ATP synthase subunit } b \text {, } \\
\text { mitochondrial }\end{array}$ & ATP5B & P06576 & 0.38 & 0.13 & 7.79 & 0.39 \\
\hline & 2967 & Keratin, type II cytoskeletal 6A & KRT6A & P02538 & 0.39 & 0.27 & 3.12 & 0.33 \\
\hline & 672 & Keratin, type I cytoskeletal I4 & KRTI4 & P02533 & 0.4 & 0.27 & 3.09 & 0.33 \\
\hline & 1111 & Annexin A2 ${ }^{\mathrm{b}}$ (lipocortin) & ANXA2 & Q8TBV2 & 0.41 & 0.68 & 1.39 & 0.39 \\
\hline & 439 & Progerin (Lamin A/C) & LMNA & Q6UYC3 & 0.41 & 0.54 & 2.77 & 0.62 \\
\hline & 534 & Keratin, type II cytoskeletal 6A & KRT6A & P02538 & 0.43 & 0.22 & 4.5 & 0.42 \\
\hline & 460 & Pyruvate kinase isozyme M2 & PKM2 & $\mathrm{PI} 4618$ & 0.46 & 0.58 & 2.58 & 0.69 \\
\hline & 739 & Keratin, type II cytoskeletal 8 & KRT8 & P05787 & 0.5 & 0.3 & 3.49 & 0.53 \\
\hline & 1586 & 14-3-3 protein $\sigma$ (stratifin) & SFN & P3।947 & 0.53 & 0.49 & 1.82 & 0.47 \\
\hline & 903 & Serpin B5 (maspin) & PI5 & P36952 & 0.7 & 0.45 & 1.6 & 0.51 \\
\hline & 915 & Keratin, type I cytoskeletal I8 & KRTI8 & P05783 & 0.76 & 0.48 & 1.75 & 0.65 \\
\hline \multirow[t]{5}{*}{$\begin{array}{l}\text { Mixed regulation } 2^{x i}<1 \\
2^{y i}>1, \text { OR } 2^{x i}>1,2^{y i}<1\end{array}$} & 2402 & $\begin{array}{l}\text { Cyclin-dependent kinase } \\
\text { inhibitor } 2 A \text {, isoforms } I / 2 / 3 \\
(p / 6)\end{array}$ & CDKN2A & P4277I & 0.34 & 4.83 & 3.46 & 5.77 \\
\hline & 645 & Keratin, type II cytoskeletal 7c & KRT7 & P08729 & 0.37 & 2.32 & 1.53 & 1.31 \\
\hline & 646 & Keratin, type II cytoskeletal 7 & KRT7 & P08729 & 0.3 & 1.6 & 2.06 & 0.97 \\
\hline & 2597 & Galectin-7 & LGALS7 & P47929 & 0.37 & 2.51 & 0.25 & 0.23 \\
\hline & 366 & HSPAIA & HSPAIA & P08I07 & 3.01 & 0.86 & 0.71 & 1.86 \\
\hline \multirow[t]{5}{*}{ Up-regulated $2^{x i}>1,2^{y i}>1$} & $|45|$ & $\begin{array}{l}\text { EF-hand domain containing } \\
\text { protein D2 }\end{array}$ & EFHD2 & Q96C19 & 1.17 & 2.06 & 0.59 & 1.42 \\
\hline & 266 & Ezrin (villin-2) & VIL2 & PI53II & 1.5 & 2.55 & 0.45 & 1.7 \\
\hline & 1685 & HSPBI (Hsp27) & HSPBI & P04792 & 2 & 1.14 & 0.44 & 1.01 \\
\hline & 2983 & Elongation factor $\mathrm{I}-\delta$ & EEFID & P29692 & 2.08 & 1.84 & 0.68 & 2.58 \\
\hline & 1186 & Inorganic pyrophosphatase & PPAI & Q1518I & 2.26 & 1.4 & 0.58 & 1.82 \\
\hline
\end{tabular}


Table 2: Spots identified by mass spectrometry (Continued)

\begin{tabular}{|c|c|c|c|c|c|c|c|}
\hline 1721 & Keratin, type I cytoskeletal 10 & KRTIO & $\mathrm{PI} 3645$ & 2.34 & 2.58 & 0.26 & 1.56 \\
\hline 1694 & HSPBI & HSPBI & P04792 & 2.48 & 1.08 & 0.47 & 1.25 \\
\hline 777 & $\alpha$-enolase & ENOI & P06733 & 2.52 & 1.25 & 0.41 & 1.3 \\
\hline 781 & $\alpha$-enolase & ENOI & $\mathrm{P} 06733$ & 2.57 & 1.27 & 0.34 & 1.12 \\
\hline 778 & $\alpha$-enolase & ENOI & $\mathrm{P} 06733$ & 2.6 & 1.28 & 0.34 & 1.15 \\
\hline 1849 & Protein DJ-I & PARK7 & Q99497 & 2.79 & 1.43 & 0.31 & 1.22 \\
\hline 382 & HSPA9 (mortalin, GRP 75) & HSPA9 & P38646 & 2.92 & 1.29 & 0.31 & 1.17 \\
\hline 766 & $\alpha$-enolase & ENOI & P06733 & 3.27 & 1.49 & 0.26 & 1.25 \\
\hline 1859 & Protein DJ-I & PARK7 & Q99497 & 3.93 & 1.58 & 0.23 & 1.45 \\
\hline 377 & HSPAIA (Hsp70-I) & HSPAIA & P08107 & 4.08 & 1.65 & 0.21 & 1.4 \\
\hline 1678 & HSPBI (Hsp27) & HSPBI & P04792 & 6.95 & 1.13 & 0.24 & 1.86 \\
\hline 1686 & HSPBI (Hsp27) & HSPBI & P04792 & 1.04 & 1.45 & 1.91 & 2.88 \\
\hline 1839 & $\begin{array}{l}\text { Thioredoxin-dependent } \\
\text { peroxide reductase, } \\
\text { mitochondrialc }\end{array}$ & PRDX3 & P30048 & 1.66 & 1.54 & 1.01 & 2.58 \\
\hline 1663 & HSPBIc (Hsp27) & HSPBI & P04792 & 4.04 & 1.59 & 2.8 & 17.97 \\
\hline
\end{tabular}

DC-I, DC-2, and DC-3 stand for direct comparisons I, 2, and 3. GC-C stands for grouped comparison C. All proteins met criteria for significance. bSignificant in group comparison A. c Significant in both group comparisons A and B. Proteins are grouped by the direction of expression for the viral oncogene-transduced cultures as compared to non-viral oncogene-expressing primary HFKs. Names and accession numbers are in the UniProt format. Note that by definition, $z_{i}=w_{i} .-\left(x_{i}+y_{j}\right)$. For this table, the $x_{i}, y_{i}, z_{i}$, and $w_{i}$ values have been exponentiated (i.e., converted to fold change) to facilitate interpretation. Proteins with values $<0.5$ and $>2.0$ represent a 2 -fold change (absolute value of $x_{i}$ or $y_{i}>1$ ). Group symbols correlate with the symbols used in Figure 4.

oncogene, heat shock proteins, a cytoskeletal protein, a regulator of apoptosis, a translation elongation factor, and other structural proteins and enzymes (see Discussion).

Above and in back of the central grey spots are 88 spots (blue) that were evaluated as significant and share the common property that $\mathrm{x}_{i}<0, \mathrm{y}_{i}<0$, that is, expression was down-regulated in E6- and E7-transduced cells. All spots in this group also shared the property $z_{i}>0\left(z_{i}\right.$ significant for circles, non-significant for squares). That is, the effect in E6/7-transduced cells was less than predicted, assuming independent E6 and E7 effects. Identified proteins in this group include a serine protease inhibitor, an apoptotic regulator, a number of intermediate filament proteins associated with differentiated epithelial cells, and several metabolic enzymes (see Discussion).

There were also only 10/741 outliers that were significantly altered in the presence of one oncogene and oppositely regulated in cell cultures expressing the other viral oncogene. These appear as turquoise and green points in the plot. We identified five of these at the molecular level. Four were down-regulated in E6-transduced cells and upregulated in E7-transduced cells, whereas one was up-regulated in E6-transduced cells and down-regulated in E7transduced cells. The identities of these proteins and possible reasons for these distinctive patterns of regulation are considered in the Discussion.

It was notable that there were only five outliers for which the increment in expression in E6/7-transduced cells was significantly greater than predicted based on individual effects in E6-transduced and E7-transduced cells (i.e., the "E6/7 interaction term" $\left(\mathrm{z}_{i}\right)$ was significant, and $\mathrm{x}_{i}, \mathrm{y}_{i^{\prime}}$ and $z_{i}$ all have the same algebraic sign). We identified two of these at the molecular level, and both proved to be charge isoforms of HSPB1 (Table 2).

\section{Shifts between protein charge isoforms}

2D gel analysis provides an ability to detect instances where a treatment leads to a shift in the distribution of 


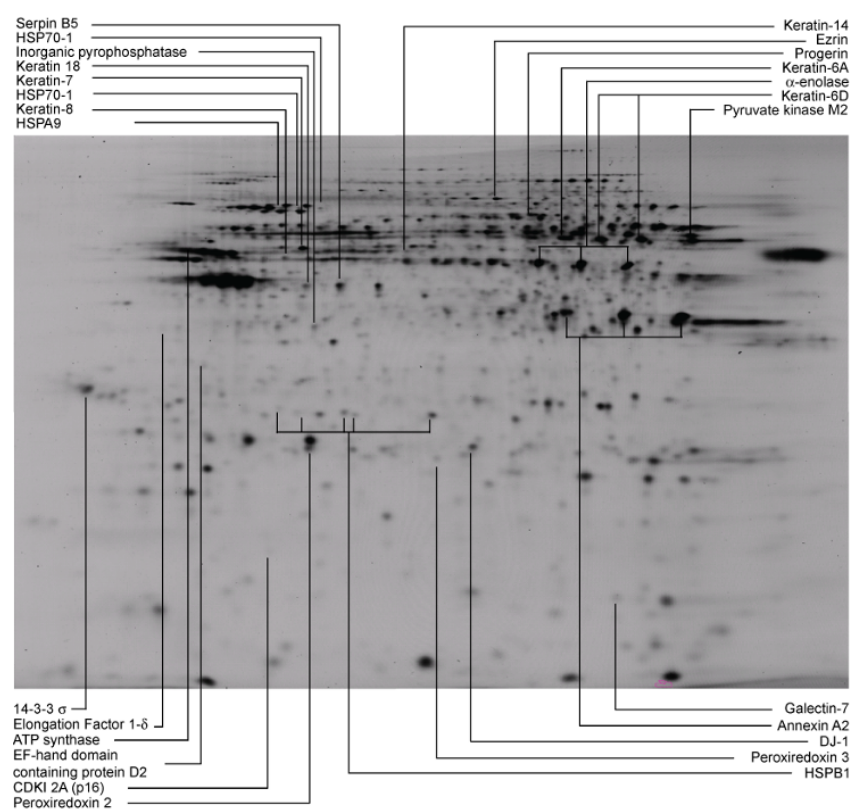

Figure 2

Identification of protein spots on 2D gel. Image depicts Cy3 (internal standard) channel for a representative gel. Proteins from each sample group and the internal standard were separated in two dimensions. Horizontal dimension is isoelectric focusing ( $\mathrm{pH} 3-10$, acidic end to left). Vertical dimension is $12.5 \%$ SDS-PAGE. Indicated spots were identified with high confidence and met criteria for statistical and biological significance. Some proteins were identified more than once because charge isoforms were present.

charge isoforms for a given protein. Charge isoforms typically manifest as a set of spots that migrate differently in the first dimension but nearly identically in the second. There were two notable instances where nearby, differentially regulated spots were verified as protein charge isoforms by mass spectrometry. Both instances involved stress proteins: HSPA1 and HSPB1 (Table 1). Representative images of the region of the 2D gels containing HSPB1 are shown in Figure 5. Based on its mobility relative to proteins in surrounding areas of the gel, Spot 1685 probably corresponds to unmodified HSPB1, whereas the other four spots have acidic modifications. As noted in the preceding section, two of the HSPB1 spots (1686 and 1663) showed significantly greater expression in E6/7transduced cells than predicted based on results in individually transduced populations, and this is readily evident from inspection of the gel images. The expression pattern is consistent with (but does not prove) the existence of one charge modification associated with E6 expression, which shifts the unmodified HSPB1 into spots 1678 and 1694, and a second modification associated only with E6/7 co-expression, which shifts this material into spots 1686 and 1663.

\section{Protein interaction map}

As an additional way to examine the relationship between identified proteins, we used the STRING tool http:// string.embl-heidelberg.de/ to prepare an interaction map (Figure 6). We included within the map p53 and Rb proteins, as these are known to be key mediators of E6 and E7 effects, respectively. Of the 24 unique identified proteins, 21 showed connectivity with at least one other protein in the map. In general, proteins with high connectivity are likely to be influential in the operation of biological networks. As might be expected, p53 has the highest connectivity (14 interactions). The molecular chaperones displayed high connectivity not only with p53, but with other identified proteins (e.g., 6 interactions in addition to p53 for HSPA9, 5 for HSPB1). Interestingly, although none of the metabolic and stress response enzymes interact directly with p53 or $\mathrm{Rb}$, they showed high connectivity with other identified proteins ( 5 interactions for enolase and 4 each for ATP synthase and peroxiredoxin 3 ).

\section{Discussion}

In this study, we compared protein expression patterns in isogenic populations of primary HFKs and human keratinocytes immortalized by the expression of HPV 16 E6 and E7 oncoproteins. Large-scale proteomic analysis, using 2D-DIGE, provided insight into patterns and trends that would not have been apparent from studies of individual proteins. Results showed that although 170 out of 741 $(23 \%)$ of the tracked proteomic features differed significantly between oncogene-transduced and primary cells, most of the changes were in the same direction and of comparable magnitude in all three transduced populations (E6, E7, or both). This phenotypic convergence was observed despite the very different mechanisms of action of E6 and E7. We suggest that these changes may not be directly associated with E6 or E7 expression, but rather are characteristic of immortalized epithelial cells, independent of the event originally driving the immortalization process. This interpretation is supported by a literature analysis, which indicates that many of the identified upand down-regulated spots show similar patterns of alteration in tumors and tumor-derived cell lines that do not express viral oncogenes.

As an example, one of the up-regulated spots was the oncoprotein DJ-1 (PARK7), which transforms mouse 3T3 cells in vitro [32] and is also elevated in many non-virally induced human cancers, including lung, breast, ovarian, thyroid, and pancreatic cancers [33-36]. Selection for DJ1 expression in cancer probably reflects its anti-apoptotic function and interaction with the PTEN signaling pathway 
A: Immunoblot
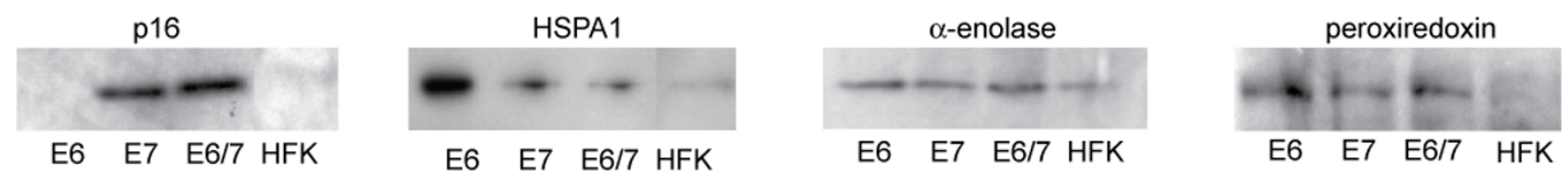

\section{B: Quantification}
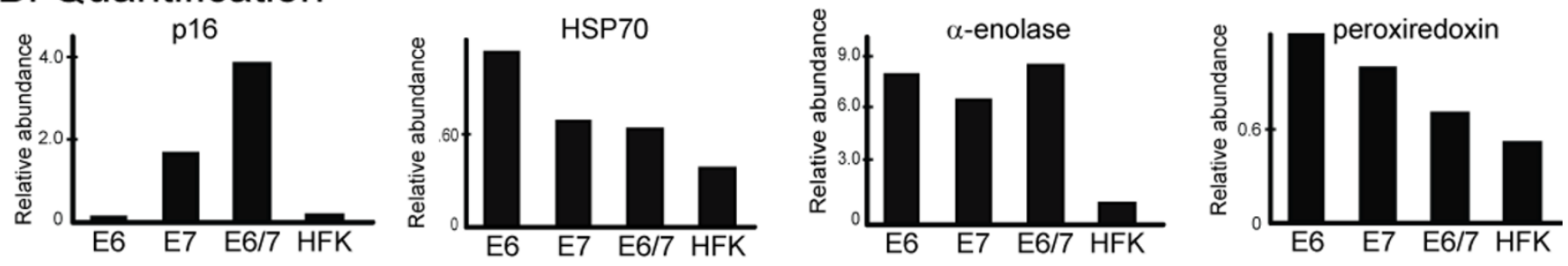

\section{C: Correlation with 2D-DIGE.}
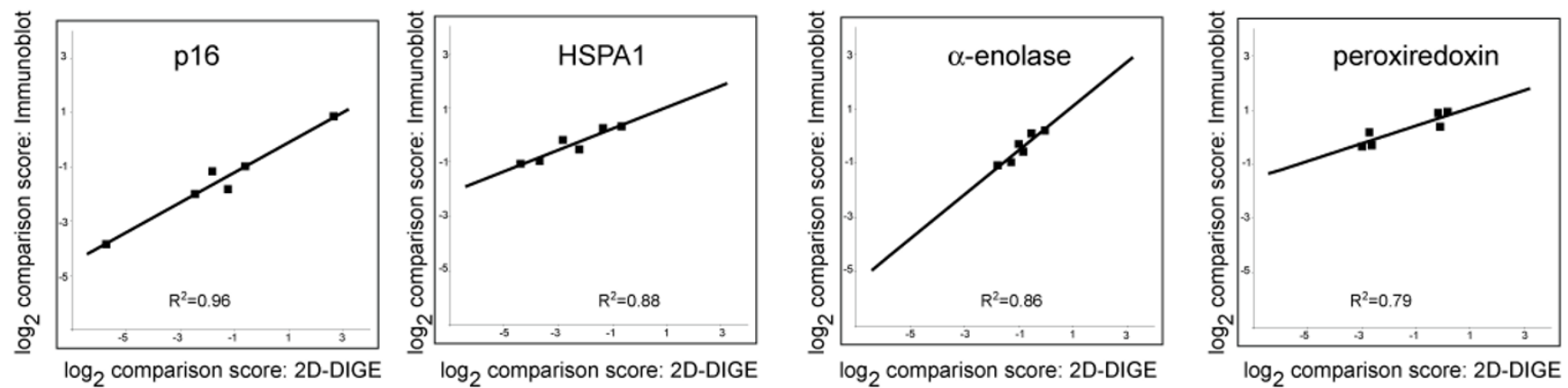

Figure 3

Correlation of immunoblot analysis and 2D-DIGE. A. Immunoblotting was performed as described in the Methods section using lysates from the same cells as for 2D-DIGE. For HSPAI, $5 \mu \mathrm{g}$ of protein extract was analyzed by $8 \%$ SDS-PAGE. For all others, $30 \mu \mathrm{g}$ extract was analyzed by I4\% SDS-PAGE. Immunoblots were developed using a fluorogenic dye (ECF, GE Healthcare). B. Quantification of the immunoblots in Panel A by Kodak ID 3.5 imaging software. C. Correlation between 2DDIGE and immunoblot results. Six intergroup comparisons were made. Three were individual comparisons: E6 v. HFK, E7 v. HFK, and E6/7 v. HFK. Three were grouped comparisons: sum of HFK and E6 v. sum of E7 and E6/7, sum of HFK and sum of E7 v. E6 and E6/7, and sum of HFK and E6/7 v. sum of E6 and E7.

$[33,34]$. There are at least five other examples of up-regulated spots that have previously been described as human epithelial cancer markers: ezrin (VIL2), a cytoskeletal protein linked to metastasis [37,38]; EF-hand domain containing protein-D2 (swiprosin-1), which regulates BCR apoptotic signaling [39]; $\alpha$-enolase, a glycolytic enzyme that is elevated in cancer cells [40-43]; Elongation factor$1 \delta$, a translation factor and proto-oncogene [44-46]; and Peroxiredoxin-3, which responds to elevated mitochondrial peroxide in cancer cells [47-51].

Among the down-regulated spots were 14-3-3 protein $\sigma$, which is a tumor suppressor that is commonly silenced in spontaneous human cancers ([52], reviewed in [53]); Cytokeratins 6 and 14, which have previously been shown to decrease in E6/7-expressing cell cultures and in many epithelial cancers, including cervical cancer [54-57]; and maspin (serpin B5), which is a serine protease inhibitor that has been observed to decrease in an E6/7-expressing in vitro model, in the progression of normal cervical epithelium to high-grade intraepithelial lesions and cervical cancer, and in non-virally induced breast cancer [58-60]. Maspin may be selected against because of its ability to influence cell adhesion, motility, angiogenesis, and apoptosis [61]. It is notable that maspin was down-regulated in E7-, as well as E6- and E6/7-transduced cultures. Maspin expression is positively regulated by p53; thus, suppression of maspin in E6- and E6/E7-expressing cultures is consistent with an E6-mediated decrease in p53 expression. The decrease in maspin in E7-expressing cultures is not, however, readily explained by this mechanism, as p53 levels typically increase, rather than decrease, in E7expressing cells $[18,62]$. 
A

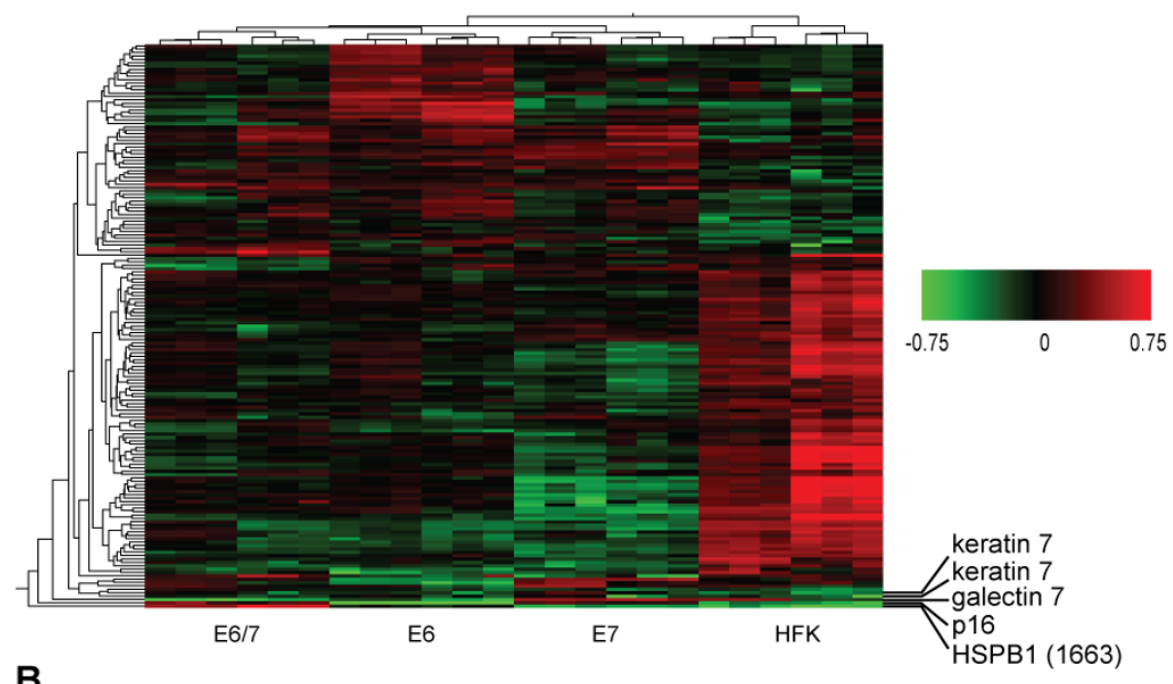

B

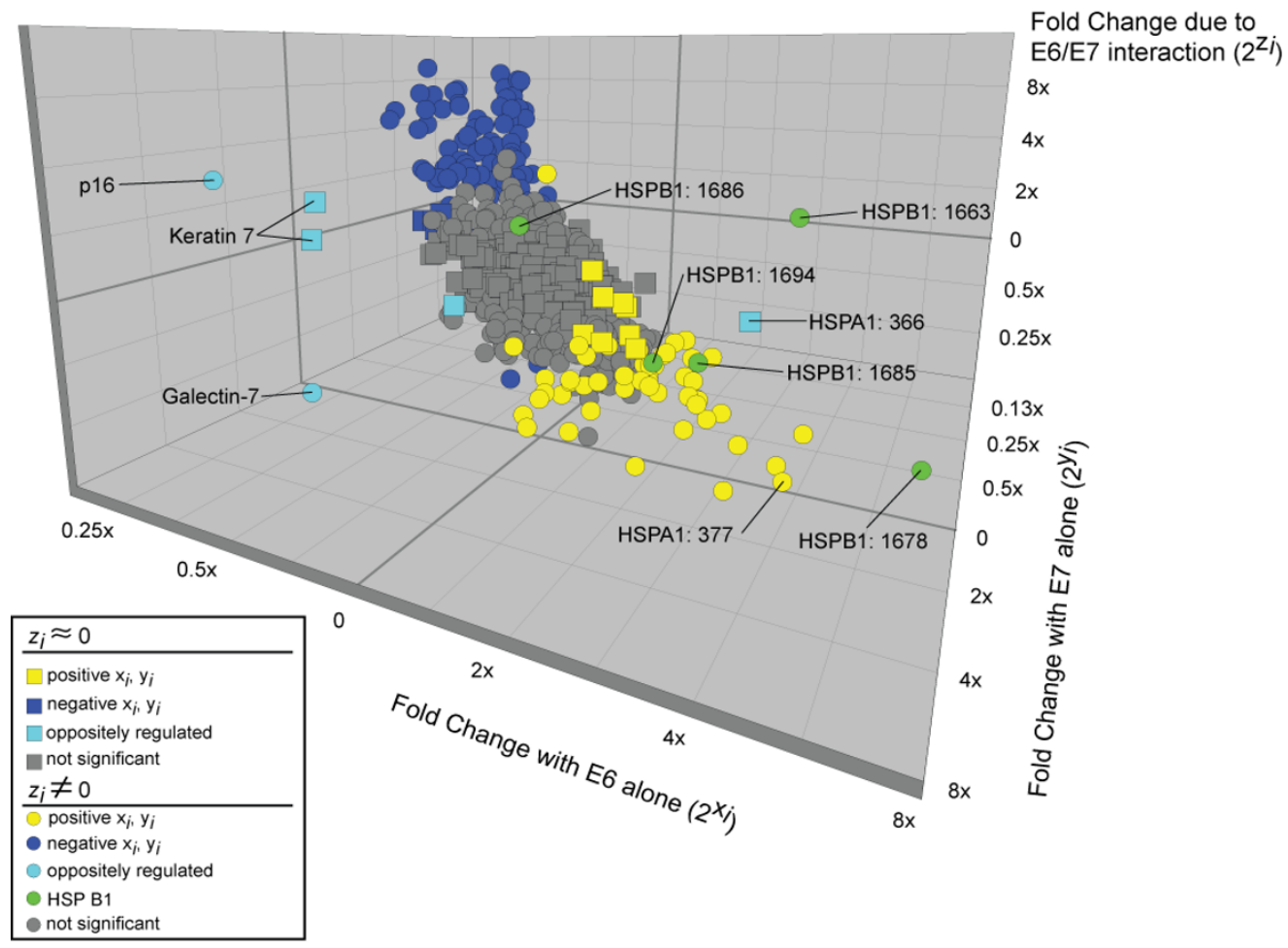

Figure 4

Proteomic patterns. Three-dimensional scatter plot of entire proteomic data set. A. Results of cluster analysis represented as heat map. Proteomic features that changed significantly in immortalized versus HFK populations were analyzed by unsupervised cluster analysis. Experimental samples are clustered on the horizontal axis and protein spots on the vertical axis. Legend indicates fold change on $\log _{10}$ scale. B. Three-dimensional scatter plot of entire proteomic data set. Axes represent fold change in expression due to E6 alone ( $\left.2^{x i}\right)$, E7 alone ( $\left.2^{y}\right)$, and the E6/7 interaction ( $\left.2^{z i}\right)$. Grey spots did not reach criteria for significance. Other spots denote proteins that were significantly up-regulated (yellow), down-regulated (blue), or showed a mixed pattern of regulation (turquoise) in E6- and E7-transduced populations (i.e., $x_{i}>0$ and $y_{i}<0$ or $x_{i}<0$ and $y_{i}>$ 0 ). Different forms of HSPBI were assigned a common color (green) to aid in visualization. Charge isoforms of HSPAI and HSPAI are labeled according to spot number in the master spot map. Shape of symbols denotes significance of $z_{i}$ (squares, not significant; circles, significant). For clarity, labels have been omitted for identified proteins in the large clusters of spots that were similarly regulated. 


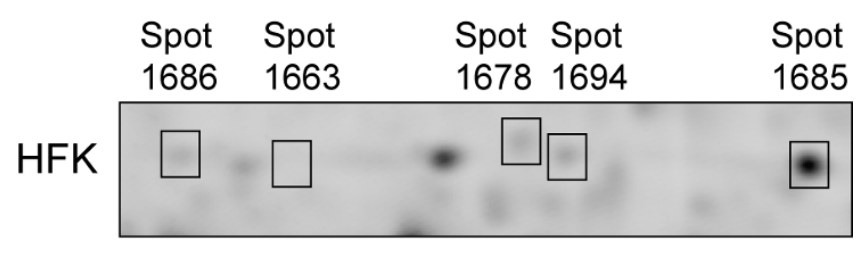

E6

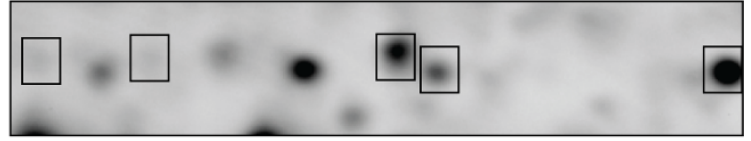

E7

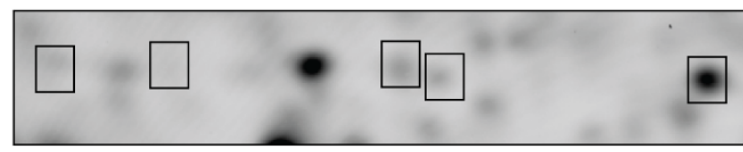

$\mathrm{E} 6 / 7$

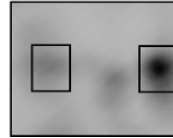

Figure 5

Enlarged view of the region of the 2D gels containing HSPB I charge forms. Representative gels from the HFK, E6, E7, and E6/7 sample groups are shown. Each panel represents one of the sample groups. Images are of the Cy5 (sample) channel only. Boxes are labeled according to master spot number. The gel is oriented as in Figure 2. The region shown spans from approximately $\mathrm{pH} 5.5$ to 6.0 .

A few proteins in our analysis stand out because they did not follow the common regulatory pattern. Expression of these proteins is evidently directly associated with E6 or E7 expression, rather than indirectly associated with immortalization. The presence of the cyclin-dependent kinase inhibitor p16 ${ }^{\text {INK4a }}$ in the group of E7-associated genes supports this assumption and can be regarded as an internal control, since p16 is known to be up-regulated as a direct consequence of $\mathrm{E7}$-mediated dissociation of the $\mathrm{Rb} / \mathrm{E} 2 \mathrm{~F} / \mathrm{HDAC}$ complex (reviewed in [63]). The observed down-regulation of $\mathrm{p} 16^{\mathrm{INK} 4 \mathrm{a}}$ in association with $\mathrm{E} 6$ is unexplained, but is consistent with a prior report [15]. Galectin-7 is another example of a protein that is induced by E7 but suppressed by E6. Galectin-7, which has proapoptotic and growth suppressive functions, is dependent on p53 for expression, which may explain its down-regulation in the E6-expressing cells $[64,65]$ and up-regulation in the E7-expressing cells. Galectin-7 is down-regulated in E6/7-transfected cells, consistent with its striking downregulation in cervical high-grade intraepithelial neoplasia [58] and the known low level of p53 in these tumors. Cytokeratin-7, a protein that is present in cervical cancer but not normal stratified squamous epithelia $[66,67]$, increased in E7-transduced cells, but decreased in E6transduced cells. A possible explanation is its reported ability, unique among the cytokeratins, to bind and stabilize E7 mRNA[68], which might provide selective pressure for overexpression in E7-transduced cells. Interestingly, Cytokeratin- 7 is present in up to $87 \%$ of cervical cancers, whereas it is absent from other epithelial cancers $[69,70]$.

There were five significant instances in which cellular protein expression in E6 and E7 co-expressing cells was increased over the sum of effects observed in cells expressing either E6- or E7 alone. Two spots in this category (spots 1663 and 1686) were identified as isoforms of HSPB1. Both migrated as more acidic than expected based on the pI calculated from their primary sequence. The acidic shift could be attributable either to phosphorylation or lysine acetylation, which have both been reported in HSPB1 $[71,72]$. We failed to detect two peptides, one spanning the Ser 78 and Ser 82 phosphorylation sites, and the other spanning the Ser 15 phosphorylation site, in tryptic digests of spots 1663 and 1686, whereas we readily detected these in digests of the other HSPB1 spots. This suggests, but does not prove, that phosphorylation occurred at Ser 15, Ser78, and/or Ser82. Ser 15, 78, and 82 are known targets of MAPKAPK-2, whereas Ser 82 is a target of the AKT kinase only [73]. It will be of interest to examine the activation state of these kinases further in HPV E6/7-expressing cells.

In parallel clinical proteomic studies, we have noted a complex pattern of HSPB1 regulation. This protein is present at high levels in cornified epithelium, consistent with its function as a cornification chaperone [74]. It declines in high-grade intraepithelial neoplasia and shows a bimodal distribution in invasive cancer, with high levels in some patients, but absent in others [31]. It will be interesting to investigate this phenomenon further and to determine whether the same sites are modified in cancer tissue as are modified in the cell culture model.

\section{Conclusion}

Mucosal squamous cell carcinomas are a leading cause of cancer death, and in many cases are linked to the expression of high-risk type HPV oncogenes. One of the goals of proteomic research is to identify features of squamous cell cancer that are attributable to long-term HPV oncoprotein expression and that might be potential targets for therapeutic intervention. We found that a small fraction of features in the observable proteome were oppositely regulated by E6 or E7 proteins and that an even smaller fraction showed evidence of cooperative regulation. We hypothesize that these proteins are directly regulated by viral oncoproteins and that they may distinguish HPVdriven cancers from cancer in general. We identified p16, Galectin-7, Cytokeratin-7, and HSPA1A as novel members of a set of proteins that are differentially regulated by E6 and E7. The presence of the known E7 target p16 ${ }^{\text {INK4a }}$ in this set of outliers reinforces its relevance of HPV-dependent gene expression. We also identified post-translation- 


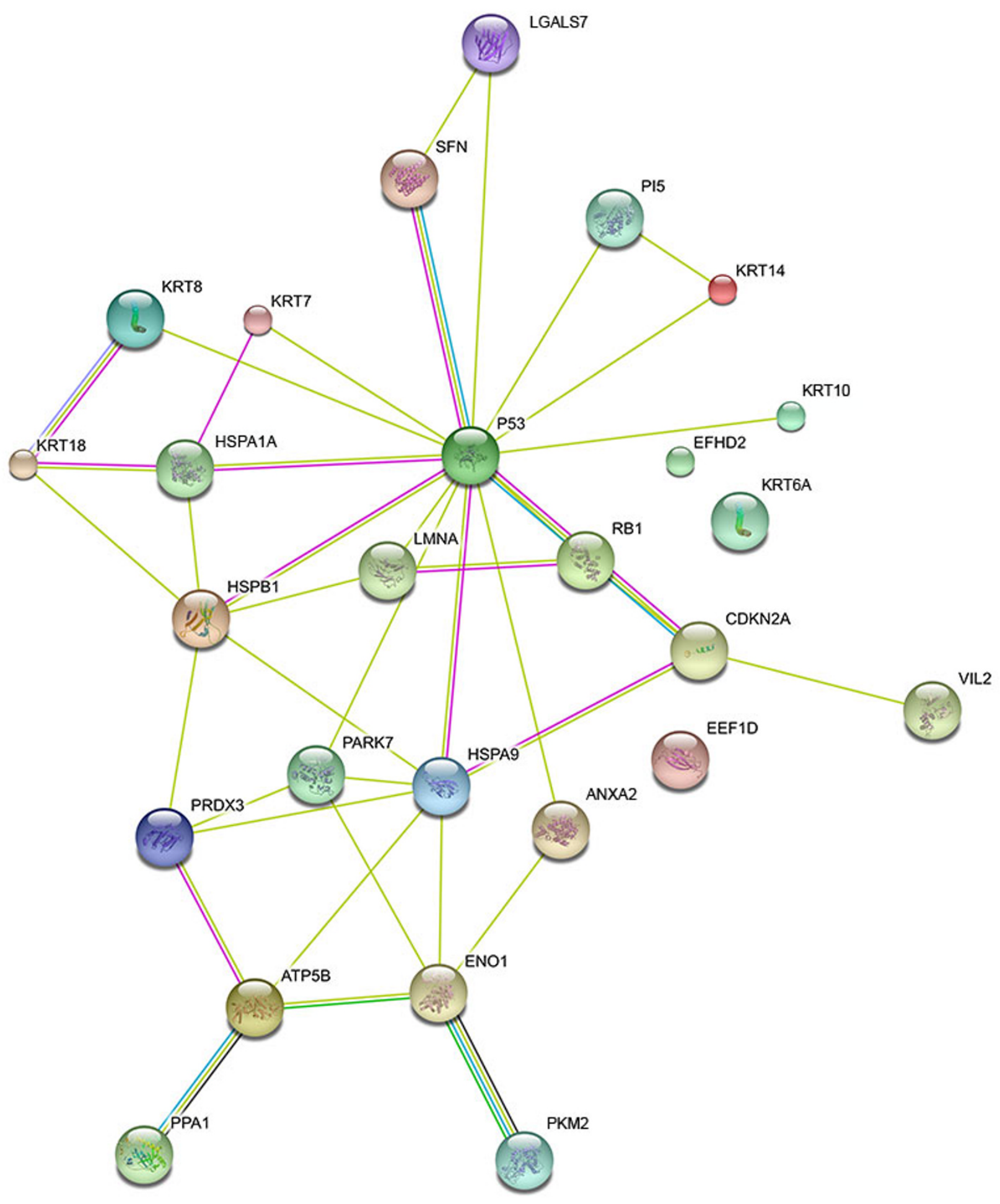

Figure 6

Protein interaction map. Map was prepared using the STRING web tool (http://string.embl-heidelberg.de/) using default parameters and the accession for identified proteins, human $\mathrm{p} 53$, and human $\mathrm{Rb}$ proteins. Colored lines denote interactions. 
ally modified forms of HSPB1 as products of E6 and E7 cooperation.

The incidence of HPV infection is much higher than HPVdriven cancers, i.e., most infections are self-limiting and clear spontaneously. An important goal of proteomics research is to identify features that distinguish cells that are merely virus-infected from those that have undergone initial steps of transformation. Regulators of cell growth and apoptosis identified in the "main sequence" of proteins are candidates to be such features. Based on this criterion, DJ-1, ezrin, Serpin B5, and annexin A2, among others, are of interest as potential markers of progression of HPV-infected cells to HPV-transformed cells.

\section{Methods \\ Cell cultures}

Primary human keratinocytes were derived from individual neonatal foreskins and grown in KSF medium (Invitrogen/GIBCO, Carlsbad, CA) supplemented with gentamycin [75]. Cells were infected with amphotrophic LXSN retroviral vectors expressing HPV 16 E6, E7, or both E6 and E7 oncogenes [26,76]. Retrovirus-infected cells were selected in $100 \mu \mathrm{g} / \mathrm{ml}$ G418 for 10 days, then passaged up to twice weekly at 1:5 dilutions. Each passage thus corresponds to approximately 2.3 population doublings. Gene transfer and viral mRNA expression were verified by polymerase chain reaction (PCR) and reverse transcriptase (RT)-PCR.

\section{D-DIGE}

To provide biological replicates, viral oncogene-expressing cultures were analyzed separately from two independent pools derived from different passage numbers of the cultures. Lysates were generated from E6-transduced cells at passage numbers 152 and 177, E7-transduced cells at passage numbers 77 and 98, and E6/7-transduced cells at passage numbers 131 and 157. Each lysate was divided into three technical replicates. Each oncogene-expressing culture was therefore represented with six-fold redundancy after data were pooled for analysis.

Cells were trypsinized, and trypsin was inactivated by medium containing $10 \%$ fetal bovine serum. Cells were collected by centrifugation, the pellets washed with PBS, and cells were lysed in $7 \mathrm{M}$ urea, $2 \mathrm{M}$ thiourea, $4 \%$ CHAPS, $40 \mathrm{mM}$ Tris-HCl $\mathrm{pH}$ 8. Aliquots were sonicated on ice and centrifuged for $12000 \mathrm{~g}$ for $5 \mathrm{~min}$ to remove debris. Protein concentrations were determined using a Bradford Assay (Bio-Rad, Hercules, CA). Five $\mu$ g of protein from each sample was labeled with Cy5 sulfhydryl-reactive dye $(0.8 \mathrm{nmol} / \mu \mathrm{g}$ protein, GE Healthcare, Buckinghamshire, UK). For the internal standard, equal amounts of each sample were combined and labeled with Cy3 sulfhydryl-reactive dye $(0.8 \mathrm{nmol} / \mu \mathrm{g}$ protein). A $24 \mathrm{~cm}$ strip holder containing a pH 3-10 nonlinear IPG strip (GE Healthcare) was used for first dimension electrophoresis. Rehydration of the strip was carried out for $15 \mathrm{~h}$ at $20^{\circ} \mathrm{C}$ with an applied electric field of $30 \mathrm{~V}$, followed by electrophoresis at $500 \mathrm{~V}$ for $2 \mathrm{~h}, 1000 \mathrm{~V}$ for $3 \mathrm{~h}$, and $8000 \mathrm{~V}$ for $7 \mathrm{~h}$. Strips were equilibrated in $100 \mathrm{mM}$ Tris- $\mathrm{HCl}(\mathrm{pH} 8)$, $6 \mathrm{M}$ urea, 30\% (v/v) glycerol, 2\% (w/v) SDS, and $32.5 \mathrm{mM}$ DTT, washed in SDS running buffer, and applied to the top of a $12.5 \%$ SDS gel $(25 \mathrm{~cm} \times 20 \mathrm{~cm} \times 0.1 \mathrm{~cm})$. Electrophoresis was performed overnight using $2 \mathrm{~W}$ per gel. Cy3 and Cy5 images were collected using a GE Healthcare Typhoon 9400 Series Variable Imager.

Quantification and data analysis were performed as described [31]. Comparisons were performed as described in Additional file 1, using Significance Analysis of Microarrays (SAM) to obtain values for parameters representing effects attributable to E6, E7, and biological interactions of E6 and E7. For each comparison, a difference (d) score and a false discovery rate (FDR) were determined by SAM (version 3.0 add-in for Microsoft Excel; available at http:/ /www-stat.stanford.edu/ tibs/SAM/) [77]. The d score represents fold change adjusted for a measure of spot-specific variance and a measure of variance within the data set as a whole, while the FDR is based on permuted data sets. Proteins for mass spectrometry analysis were chosen from among the top-ranked proteins in each comparison. Mass spectrometry was performed as described [31].

\section{Immunoblotting}

Cells were suspended in SDS sample buffer and heated for $3 \mathrm{~min}$ at $100^{\circ} \mathrm{C}$. The protein concentration was determined using a DC Protein Assay kit (Bio-Rad Laboratories, Hercules, CA). Proteins were separated by $14 \%$ SDSPAGE, blotted onto PVDF membranes (Immobilon-P Transfer Membranes, Millipore Corporation, Bedford, $\mathrm{MA}$ ) and probed with monoclonal antibodies against p16 INK4a (G175-405, BD Biosciences, San Jose, CA), Peroxiredoxin-3 (ab16752, Abcam, Cambridge, MA), $\alpha$-enolase (sc-7455, Santa Cruz Biotechnology, Santa Cruz, CA), or HSPA1(C92F3A-5, Assay Designs Inc., Ann Arbor, MI). Chemiluminescence detection was performed using an ECL kit (Amersham, GE Healthcare). Blots were imaged using the Kodak Image Station CF 440 and analyzed using Kodak 1D 3.5 imaging software (Eastman Kodak, Rochester, NY).

\section{Competing interests}

The authors declare that they have no competing interests.

\section{Authors' contributions}

MAM performed the main proteomic experiments and data analysis and drafted the manuscript. EH assisted in the creation of the cell lines, and HA contributed to the initial phase of the proteomic experiments. RHP created 
the detailed experimental design and performed statistical analysis. DGF helped conceive the research. WSD supervised data collection and analysis and served as MAM's dissertation advisor. HS is a virologist who conceived the study and created the cell populations that were analyzed. All authors had the opportunity to revise the manuscript for intellectual content and approved the final version.

\section{Authors' information}

MAM performed this work in partial fulfillment of the requirements for the $\mathrm{MD} / \mathrm{PhD}$ program, Medical College of Georgia. EH was an Assistant Research Scientist and is a molecular biologist. HA was a postdoctoral fellow and is an expert in proteomic analysis. RHP is an Assistant Professor and statistician. DGF is a Professor, family physician, and global health researcher. WSD is a Professor and molecular biologist. HS was an Associate Professor and virologist. WSD is the Principal Investigator for the award that supported the work, and RHP, DGF, and HS were coinvestigators.

\section{Additional material}

\section{Additional file 1}

Supplemental materials.

Click here for file

[http://www.biomedcentral.com/content/supplementary/14775956-7-29-S1.doc]

\section{Acknowledgements}

This work was in part supported by NIH Grant 5R33CA09594I-04. We thank Eric Miller of the Medical College of Georgia Proteomics Core Laboratory and Dr. Rhea-Beth Markowitz of the MCG Office of Scientific Editorial Support for their contributions.

\section{References}

I. de Villiers EM, Fauquet C, Broker TR, Bernard HU, zur Hausen H: Classification of papillomaviruses. Virology 2004, 324: 17-27.

2. Munoz N: Human papillomavirus and cancer: the epidemiological evidence. J Clin Virol 2000, 19:1-5.

3. Franceschi S, Munoz N, Bosch XF, Snijders PJ, Walboomers JM: Human papillomavirus and cancers of the upper aerodigestive tract: a review of epidemiological and experimental evidence. Cancer Epidemiol Biomarkers Prev 1996, 5:567-575.

4. Herrero R, Castellsague X, Pawlita M, Lissowska J, Kee F, Balaram P, Rajkumar T, Sridhar H, Rose B, Pintos J, et al.: Human papillomavirus and oral cancer: the International Agency for Research on Cancer multicenter study. J Natl Cancer Inst 2003, 95: $1772-1783$.

5. Ragin CCR, Modugno F, Gollin SM: The Epidemiology and Risk Factors of Head and Neck Cancer: a Focus on Human Papillomavirus. J Dent Res 2007, 86: I04-I I4.

6. Schwartz SM, Daling JR, Doody DR, Wipf GC, Carter JJ, Madeleine MM, Mao EJ, Fitzgibbons ED, Huang S, Beckmann AM, et al.: Oral cancer risk in relation to sexual history and evidence of human papillomavirus infection. J Natl Cancer Inst 1998, 90:1626-1636.

7. Smith EM, Ritchie JM, Summersgill KF, Klussmann JP, Lee JH, Wang D, Haugen TH, Turek LP: Age, sexual behavior and human papillomavirus infection in oral cavity and oropharyngeal cancers. Int J Cancer 2004, 108:766-772.
8. Weinberger PM, Yu Z, Haffty BG, Kowalski D, Harigopal M, Brandsma J, Sasaki C, Joe J, Camp RL, Rimm DL, Psyrri A: Molecular classification identifies a subset of human papillomavirus associated oropharyngeal cancers with favorable prognosis. J Clin Oncol 2006, 24:736-747.

9. Doorbar J: Molecular biology of human papillomavirus infection and cervical cancer. Clin Sci (Lond) 2006, I I 0:525-54 I.

10. zur Hausen $\mathrm{H}$ : Papillomaviruses and cancer: from basic studies to clinical application. Nat Rev Cancer 2002, 2:342-350.

II. James MA, Lee JH, Klingelhutz AJ: Human papillomavirus type 16 E6 activates NF-kappaB, induces cIAP-2 expression, and protects against apoptosis in a PDZ binding motif-dependent manner. J Virol 2006, 80:530I-5307.

12. Ronco LV, Karpova AY, Vidal M, Howley PM: Human papillomavirus 16 E6 oncoprotein binds to interferon regulatory factor3 and inhibits its transcriptional activity. Genes Dev 1998, | 2:206 |-2072.

13. Thomas MC, Chiang CM: E6 oncoprotein represses p53dependent gene activation via inhibition of protein acetylation independently of inducing p53 degradation. Mol Cell 2005, I7:25I-264.

14. Kelley ML, Keiger KE, Lee C], Huibregtse JM: The global transcriptional effects of the human papillomavirus $E 6$ protein in cervical carcinoma cell lines are mediated by the E6AP ubiquitin ligase. J Virol 2005, 79:3737-3747.

15. Shai A, Brake T, Somoza C, Lambert PF: The human papillomavirus $\mathrm{E} 6$ oncogene dysregulates the cell cycle and contributes to cervical carcinogenesis through two independent activities. Cancer Res 2007, 67:1626-1635.

16. Shai A, Nguyen ML, Wagstaff J, Jiang YH, Lambert PF: HPVI6 E6 confers p53-dependent and p53-independent phenotypes in the epidermis of mice deficient for E6AP. Oncogene 2007, 26:332I-3328.

17. Munger K, Baldwin A, Edwards KM, Hayakawa $\mathrm{H}$, Nguyen $\mathrm{CL}$, Owens $M$, Grace $M$, Huh K: Mechanisms of human papillomavirusinduced oncogenesis. J Virol 2004, 78: | | 45 I-I | 460.

18. Jones DL, Thompson DA, Munger K: Destabilization of the RB tumor suppressor protein and stabilization of $\mathrm{p} 53$ contribute to HPV type 16 E7-induced apoptosis. Virology 1997, 239:97-107.

19. Zerfass K, Schulze A, Spitkovsky D, Friedman V, Henglein B, JansenDurr P: Sequential activation of cyclin $E$ and cyclin $A$ gene expression by human papillomavirus type 16 E7 through sequences necessary for transformation. I Virol 1995, 69:6389-6399.

20. Cordano P, Gillan V, Bratlie S, Bouvard V, Banks L, Tommasino M, Campo MS: The E6E7 oncoproteins of cutaneous human papillomavirus type 38 interfere with the interferon pathway. Virology 2008, 377:408-418.

21. Um S], Rhyu JW, Kim EJ, Jeon KC, Hwang ES, Park JS: Abrogation of IRF-I response by high-risk HPV E7 protein in vivo. Cancer Lett 2002, I79:205-2I2.

22. Bond JA, Haughton MF, Rowson JM, Smith PJ, Gire V, Wynford-Thomas D, Wyllie FS: Control of replicative life span in human cells: barriers to clonal expansion intermediate between $\mathrm{MI}$ senescence and M2 crisis. Mol Cell Biol 1999, 19:3103-3II4.

23. Duensing $\mathrm{S}$, Munger K: Centrosome abnormalities and genomic instability induced by human papillomavirus oncoproteins. Prog Cell Cycle Res 2003, 5:383-39I.

24. Munger K, Phelps WC, Bubb V, Howley PM, Schlegel R: The E6 and E7 genes of the human papillomavirus type 16 together are necessary and sufficient for transformation of primary human keratinocytes. J Virol 1989, 63:44I7-442I.

25. Plug-DeMaggio AW, Sundsvold T, Wurscher MA, Koop II, Klingelhutz AJ, McDougall JK: Telomere erosion and chromosomal instability in cells expressing the HPV oncogene 16E6. Oncogene 2004, 23:356I-357I.

26. Stoppler H, Stoppler MC, Johnson E, Simbulan-Rosenthal CM, Smulson ME, lyer S, Rosenthal DS, Schlegel R: The E7 protein of human papillomavirus type 16 sensitizes primary human keratinocytes to apoptosis. Oncogene 1998, 17:1207-1214.

27. Unlu M, Morgan ME, Minden JS: Difference gel electrophoresis: a single gel method for detecting changes in protein extracts. Electrophoresis 1997, I 8:207|-2077.

28. Lee KA, Shim JH, Kho CW, Park SG, Park BC, Kim JW, Lim JS, Choe YK, Paik SG, Yoon DY: Protein profiling and identification of 
modulators regulated by the E7 oncogene in the C33A cell line by proteomics and genomics. Proteomics 2004, 4:839-848.

29. Lee KA, Kang JW, Shim JH, Kho CW, Park SG, Lee HG, Paik SG, Lim $J S$, Yoon DY: Protein profiling and identification of modulators regulated by human papillomavirus $16 \mathrm{E7}$ oncogene in HaCaT keratinocytes by proteomics. Gynecol Oncol 2005, 99:142-152.

30. Yim EK, Meoyng J, Namakoong SE, Um SJ, Park JS: Genomic and proteomic expression patterns in HPV-16 E6 gene transfected stable human carcinoma cell lines. DNA Cell Biol 2004, 23:826-835

31. Arnouk H, Merkley MA, Podolsky RH, Stoppler H, Santos C, Alvarez $M$, Mariategui J, Ferris D, Lee JR, Dynan WS: Characterization of Molecular Markers Indicative of Cervical Cancer Progression. Proteomics: Clinical Applications 2009, 3:5 I6-527.

32. Nagakubo D, Taira T, Kitaura H, Ikeda M, Tamai K, Iguchi-Ariga SM, Ariga $H$ : DJ-I, a novel oncogene which transforms mouse NIH3T3 cells in cooperation with ras. Biochem Biophys Res Com mun 1997, 23 I:509-513.

33. Davidson B, Hadar R, Schlossberg A, Sternlicht T, Slipicevic A, Skrede $M$, Risberg B, Florenes VA, Kopolovic J, Reich R: Expression and clinical role of $D J-I$, a negative regulator of PTEN, in ovarian carcinoma. Hum Pathol 2008, 39:87-95

34. Kim RH, Peters M, Jang Y, Shi W, Pintilie M, Fletcher GC, DeLuca C, Liepa J, Zhou L, Snow B, et al.: DJ-I, a novel regulator of the tumor suppressor PTEN. Cancer Cell 2005, 7:263-273.

35. Le Naour F, Misek DE, Krause MC, Deneux L, Giordano TJ, Scholl S, Hanash SM: Proteomics-based identification of RS/DJ-I as a novel circulating tumor antigen in breast cancer. Clin Cancer Res 2001, 7:3328-3335.

36. Melle C, Ernst G, Escher N, Hartmann D, Schimmel B, Bleul A Thieme H, Kaufmann R, Felix K, Friess HM, et al:: Protein profiling of microdissected pancreas carcinoma and identification of HSP27 as a potential serum marker. Clin Chem 2007, 53:629-635

37. Khanna C, Wan X, Bose S, Cassaday R, Olomu O, Mendoza A, Yeung C, Gorlick R, Hewitt SM, Helman L): The membrane-cytoskeleton linker ezrin is necessary for osteosarcoma metastasis. Nat Med 2004, 10:182-186.

38. Yu Y, Khan J, Khanna C, Helman L, Meltzer PS, Merlino G: Expression profiling identifies the cytoskeletal organizer ezrin and the developmental homeoprotein Six-I as key metastatic regulators. Nat Med 2004, I0: 175-I8I.

39. Avramidou A, Kroczek C, Lang C, Schuh W, Jack HM, Mielenz D: The novel adaptor protein Swiprosin-I enhances BCR signals and contributes to BCR-induced apoptosis. Cell Death Differ 2007, I4:1936-1947.

40. Bae SM, Lee CH, Cho YL, Nam KH, Kim YW, Kim CK, Han BD, Lee YJ, Chun HJ, Ahn WS: Two-dimensional gel analysis of protein expression profile in squamous cervical cancer patients. Gynecol Oncol 2005, 99:26-35.

4I. He P, Naka T, Serada S, Fujimoto M, Tanaka T, Hashimoto S, Shima Y, Yamadori T, Suzuki H, Hirashima T, et al.: Proteomics-based identification of alpha-enolase as a tumor antigen in nonsmall lung cancer. Cancer Sci 2007, 98: I 234- I240.

42. Li C, Xiao Z, Chen Z, Zhang X, Li J, Wu X, Li X, Yi H, Li M, Zhu G, Liang S: Proteome analysis of human lung squamous carcinoma. Proteomics 2006, 6:547-558.

43. Onda T, Uzawa K, Nakashima D, Saito K, Iwadate $Y$, Seki N, Shibahara T, Tanzawa H: Lin-7C/VELI3/MALS-3: an essential component in metastasis of human squamous cell carcinoma. Cancer Res 2007, 67:9643-9648.

44. De Bortoli M, Castellino RC, Lu XY, Deyo J, Sturla LM, Adesina AM, Perlaky L, Pomeroy SL, Lau CC, Man TK, et al.: Medulloblastoma outcome is adversely associated with overexpression of EEFID, RPL30, and RPS20 on the long arm of chromosome 8. BMC Cancer 2006, 6:223.

45. Joseph P, Lei YX, Whong WZ, Ong TM: Oncogenic potential of mouse translation elongation factor-I delta, a novel cadmium-responsive proto-oncogene. I Biol Chem 2002, 277:6|3|-6|36.

46. Kato H, Uzawa K, Onda T, Kato Y, Saito K, Nakashima D, Ogawara $\mathrm{K}$, Bukawa H, Yokoe H, Tanzawa H: Down-regulation of ID-myoinositol 1,4,5-trisphosphate 3-kinase A protein expression in oral squamous cell carcinoma. Int ] Oncol 2006, 28:873-88 I.
47. Kinnula VL, Lehtonen S, Sormunen R, Kaarteenaho-Wiik R, Kang SW, Rhee SG, Soini Y: Overexpression of peroxiredoxins I, II, III, V, and $\mathrm{VI}$ in malignant mesothelioma. J Pathol 2002, 196:316-323.

48. Chang TS, Cho CS, Park S, Yu S, Kang SW, Rhee SG: Peroxiredoxin III, a mitochondrion-specific peroxidase, regulates apoptotic signaling by mitochondria. J Biol Chem 2004, 279:4I975-4I984.

49. Choi JH, Kim TN, Kim S, Baek SH, Kim JH, Lee SR, Kim JR: Overexpression of mitochondrial thioredoxin reductase and peroxiredoxin III in hepatocellular carcinomas. Anticancer Res 2002, 22:3331-3335.

50. Karihtala P, Mantyniemi A, Kang SW, Kinnula VL, Soini Y: Peroxiredoxins in breast carcinoma. Clin Cancer Res 2003, 9:34I 8-3424.

5I. Noh DY, Ahn SJ, Lee RA, Kim SW, Park IA, Chae HZ: Overexpression of peroxiredoxin in human breast cancer. Anticancer Res 200I, $21: 2085-2090$.

52. Lodygin $\mathrm{D}$, Hermeking $\mathrm{H}$ : Epigenetic silencing of 14-3-3sigma in cancer. Semin Cancer Biol 2006, 16:2। 4-224.

53. James MA, Lee JH, Klingelhutz A): Human Papillomavirus Type 16 E6 Activates NF-\{kappa\}B, Induces clAP-2 Expression, and Protects against Apoptosis in a PDZ Binding MotifDependent Manner. J Virol 2006, 80:530I-5307.

54. Kaur P, McDougall JK: HPV-18 immortalization of human keratinocytes. Virology 1989, I73:302-310.

55. Baak JP, Kruse AJ, Garland SM, Skaland I, Janssen EA, Tabrizi S, Fagerheim S, Robboy S, Nilsen ST: Combined p53 and retinoblastoma protein detection identifies persistent and regressive cervical high-grade squamous intraepithelial lesions. Am J Surg Pathol 2005, 29: 1062-1066.

56. Southern SA, McDicken IW, Herrington CS: Loss of cytokeratin I4 expression is related to human papillomavirus type and lesion grade in squamous intraepithelial lesions of the cervix. Hum Pathol 200 I, 32: I 35I-I355.

57. Stoler A, Kopan R, Duvic M, Fuchs E: Use of monospecific antisera and cRNA probes to localize the major changes in keratin expression during normal and abnormal epidermal differentiation. J Cell Biol 1988, 107:427-446.

58. Gu Y, Wu SL, Meyer JL, Hancock WS, Burg LJ, Linder J, Hanlon DW Karger BL: Proteomic Analysis of High-Grade Dysplastic Cervical Cells Obtained from ThinPrep Slides Using Laser Capture Microdissection and Mass Spectrometry. J Proteome Res 2007, 6(II):4256-68. Epub 2007 Sep 29

59. Toussaint-Smith E, Donner DB, Roman A: Expression of human papillomavirus type $16 \mathrm{E} 6$ and E7 oncoproteins in primary foreskin keratinocytes is sufficient to alter the expression of angiogenic factors. Oncogene 2004, 23:2988-2995.

60. Xu C, Quddus MR, Sung CJ, Steinhoff MM, Zhang C, Lawrence WD: Maspin expression in CIN 3, microinvasive squamous cell carcinoma, and invasive squamous cell carcinoma of the uterine cervix. Mod Pathol 2005, I 8: I 1 02-1 I 06.

61. Khalkhali-Ellis Z: Maspin: the new frontier. Clin Cancer Res 2006 , I 2:7279-7283.

62. Demers GW, Halbert CL, Galloway DA: Elevated wild-type p53 protein levels in human epithelial cell lines immortalized by the human papillomavirus type 16 E7 gene. Virology 1994, 198:169-174.

63. Yildiz IZ, Usubutun A, Firat P, Ayhan A, Kucukali T: Efficiency of immunohistochemical pl6 expression and HPV typing in cervical squamous intraepithelial lesion grading and review of the pl6 literature. Pathol Res Pract 2007, 203:445-449.

64. Polyak K, Xia Y, Zweier JL, Kinzler KW, Vogelstein B: A model for p53-induced apoptosis. Nature 1997, 389:300-305.

65. Saussez S, Kiss R: Galectin-7. Cell Mol Life Sci 2006, 63:686-697.

66. Smedts F, Ramaekers F, Troyanovsky S, Pruszczynski M, Robben H, Lane B, Leigh I, Plantema F, Vooijs P: Basal-cell keratins in cervical reserve cells and a comparison to their expression in cervical intraepithelial neoplasia. Am J Pathol 1992, 140:60I-612.

67. Smedts F, Ramaekers FC, Vooijs PG: The dynamics of keratin expression in malignant transformation of cervical epithelium: a review. Obstet Gynecol 1993, 82:465.

68. Kanduc D: Translational regulation of human papillomavirus type 16 E7 mRNA by the peptide SEQIKA, shared by rabbit alpha(I)-globin and human cytokeratin 7. J Virol 2002, 76:7040-7048.

69. Chu P, Wu E, Weiss LM: Cytokeratin 7 and cytokeratin 20 expression in epithelial neoplasms: a survey of $\mathbf{4 3 5}$ cases. Mod Pathol 2000, I3:962-972. 
70. Smedts F, Ramaekers F, Link M, Lauerova L, Troyanovsky S, Schijf C, Vooijs GP: Detection of keratin subtypes in routinely processed cervical tissue: implications for tumour classification and the study of cervix cancer aetiology. Virchows Arch 1994, 425: 145-I55.

71. de Graauw M, Tijdens I, Cramer R, Corless S, Timms JF, Water B van de: Heat shock protein $\mathbf{2 7}$ is the major differentially phosphorylated protein involved in renal epithelial cellular stress response and controls focal adhesion organization and apoptosis. J Biol Chem 2005, 280:29885-29898.

72. Landry J, Lambert H, Zhou M, Lavoie JN, Hickey E, Weber LA, Anderson CW: Human HSP27 is phosphorylated at serines 78 and 82 by heat shock and mitogen-activated kinases that recognize the same amino acid motif as S6 kinase II. J Biol Chem 1992, 267:794-803.

73. Xiao H, Neuveut C, Benkirane M, Jeang K-T: Interaction of the Second Coding Exon of Tat with Human EF-I [delta] Delineates a Mechanism for HIV-I-Mediated Shut-Off of Host mRNA Translation. Biochemical and Biophysical Research Communications 1998, 244:384-389.

74. Jonak C, Klosner G, Kokesch C, D FO, H HO, Trautinger F: Subcorneal colocalization of the small heat shock protein, hsp27, with keratins and proteins of the cornified cell envelope. Br J Dermatol 2002, 147:13-19.

75. Schlegel R, Phelps WC, Zhang YL, Barbosa M: Quantitative keratinocyte assay detects two biological activities of human papillomavirus DNA and identifies viral types associated with cervical carcinoma. Embo J 1988, 7:3|8I-3|87.

76. Sherman L, Schlegel R: Serum- and calcium-induced differentiation of human keratinocytes is inhibited by the $E 6$ oncoprotein of human papillomavirus type 16. J Virol 1996, 70:3269-3279.

77. Tusher VG, Tibshirani R, Chu G: Significance analysis of microarrays applied to the ionizing radiation response. PNAS 200I, 98:5||6-5|2|.

Publish with Bio Med Central and every scientist can read your work free of charge

"BioMed Central will be the most significant development for disseminating the results of biomedical research in our lifetime. "

Sir Paul Nurse, Cancer Research UK

Your research papers will be:

- available free of charge to the entire biomedical community

- peer reviewed and published immediately upon acceptance

- cited in PubMed and archived on PubMed Central

- yours - you keep the copyright
BioMedcentral 